Original Article

\title{
A COMPARATIVE PHARMACOGNOSTICAL EVALUATION OF THREE BOTANICAL SOURCE PLANTS OF JIVANTI
}

\author{
RAGHAVENDRA NAIK ${ }^{*}$, HARISHA C. R. $^{2}$, RABINARAYAN ACHARYA ${ }^{3}$
}

${ }^{1}$ Research Officer (Ayurveda), Regional Ayurveda Research Institute for Metabolic Disorders, Jayanagar, Bengaluru-11, ${ }^{2} H e a d$, Pharmacognosy Laboratory, IPGT and RA, Gujarat Ayurved University, Jamnagar, Gujarat, India. ${ }^{3}$ Professor \& Head, Department of Dravyaguna, IPGT and RA, Gujarat Ayurved University, Jamnagar, Gujarat, India Email: ayuraghu@gmail.com

Received: 04 Oct 2017 Revised and Accepted: 21 Dec 2017

\section{ABSTRACT}

Objective: This study was undertaken to carry out a comparative pharmacognostical evaluation of three botanical source plants used in the name of classical Ayurvedic drug Jivanti.

Methods: Leaves of three source plants of jivanti belonging to Asclepiadaceae family i.e. Leptadenia reticulata (Retz.), Holostemma ada-kodien Schult. and Wattakaka volubilis (Linn. f.) Stapf were evaluated for morphological and microscopical characters including quantitative microscopy, surface study, powder microscopy and histochemical studies.

Results: Morphologically all the three species showed some similar characters like simple, opposite leaves with reticulate venation. The shape of the leaves were ovate to oblong in $L$ reticulata and $H$ ada-kodien whereas $W$ volubilis was having broadly ovate or suborbicular leaves. Multicellular glandular warty trichomes, rosette crystals of calcium oxalate, lactiferous cells were observed in all the three species whereas prismatic crystals were also present in $W$ volubilis. Palisade ratio and stomatal index were higher in $H$ ada-kodien followed by $L$ reticulata. Characteristic differences in the organoleptic characters like colour, taste, touch were observed in individual powder samples. Test for lignin, calcium oxalate crystal, starch grain and tannin showed a positive result in all the three samples.

Conclusion: The present study reports specific pharmacognostical characteristics for the identification and differentiation of each botanical source plant. The observed results can also serve as a reference for any further investigations.

Keywords: Holostemma ada-kodien Schult, Jivanti, Leptadenia reticulata (Retz.), Pharmacognosy, Wattakaka volubilis (Linn. f.) Stapf.

(C) 2018 The Authors. Published by Innovare Academic Sciences Pvt Ltd. This is an open access article under the CC BY license (http://creativecommons.org/licenses/by/4.0/) DOI: http://dx.doi.org/10.22159/ijpps.2018v10i2.22915

\section{INTRODUCTION}

Jivanti is one of the important medicinal herbs having immense medicinal excellence described in almost all classical texts of Âyurveda. Classical texts of Āyurveda highlighted jivanti as the best vegetable (șreștha śāka) to be consumed for maintaining the good health [1]. But, the botanical source of jivanti is in the state of controversy. Though Leptadenia reticulata (Retz) is accepted as an official botanical source[2], various herbs are used under the name of jivanti in the different parts of the country, namely Wattakaka volubilis, Holostemma ada-kodien Schult, Dendrobium macraei Lindl etc. [3]. Use of these botanicals may be due to different regional names, wide availability in the natural source as well as in local market etc.

Evaluation of plant materials through their pharmacognostical characters plays a very significant role in in the area of authentication of correct plant source. In standardization of a crude drug, macroscopic and microscopic evaluation is the primary step. The original and basic approach towards pharmacognosy includes the study of morphological characters, cell structures, organization and study of tissue system, which holds an important role in the identification and the better understanding of the correct species of the plant and also helps to differentiate between closely resembled species. According to world health organization (WHO), botanical standard investigations like epidermal cells, stomatal index etc are mandatory for the diagnosis of the herbal crude drug [4,5].

Review of literature shows that only a few preliminary works have been carried out regarding their pharmacognostical study. A detailed and comparative pharmacognostical evaluation of different source plants of jivanti is still lacking. Hence, in the present study, three source plants of jivanti i.e. Leptadenia reticulata (Retz.), Holostemma ada-kodien Schult. and Wattakaka volubilis (Linn. f.) Stapf were studied in detail to establish their differential botanical characters.

\section{MATERIALS AND METHODS}

\section{Chemicals and reagents}

All the chemicals used in the study i.e. Phloroglucinol, Conc. HCL, Iodine and Ferric chloride are of analytical grade and purchased from Sigma-Aldrich, India.

\section{Collection and preservation of the sample}

All the plant materials were identified on the basis of their morphological characters with the help of local plant collectors, botanical texts and flora [6, 7]. The collected plant materials were authenticated by an expert taxonomist. Leaves of Leptadenia reticulata (Retz.) were collected from Sasoi botanical garden and Gujarat Ayurved University (GAU) botanical garden. Holostemma ada-kodien Schult. and Wattakaka volubilis (Linn. f.) Stapf. were collected from Rakha khatia forest area of Jamnagar, Gujarat during September 2015. All the plant materials were collected following standard collection practices. Colour photographs were taken during collection and herbarium specimen of each sample were prepared following standard guidelines. Sample specimen of each drug was deposited to pharmacognosy museum, G. A. U., Jamnagar. (Specimen No-PHM 6202-Leptadenia reticulata (Retz.), PHM 6207Holostemma ada-kodien Schult., PHM 6208-Wattakaka volubilis (Linn. f.) Stapf., PHM 6209-Dendrobium macraei Lindl) for future references.

\section{Morphological study}

The morphological study includes size, shape, apex, margin, venation, base, petiole, surface, the color of leaves of $L$ reticulata, $H$ ada-kodien and $W$ volubilis.

\section{Microscopical study}

Detailed microscopic characters were studied by taking freehand thin transverse section. Sections were stained with Phloroglucinol 
and Hydrochloric acid to notice the lignified elements like fibers, vessels etc $[8,9]$. Photographs of the section were taken with the help of Canon digital camera attached to Zeiss microscope.

\section{Quantitative microscopy}

Quantitative microscopy was carried out to determine epidermal cell number, stomatal number, stomatal index and size of the stomata [10].

\section{Powder microscopy}

Dried leaf powder of all the three species was studied following standard procedures[11]. The microphotographs were taken by using Carl zeiss trinocular microscope.

\section{Histochemical test}

To confirm the presence and absence of the chemical constituents the material were subjected to various tests. The histo-chemical tests were carried out according to the standard guidelines of practical pharmacognosy [12].

\section{RESULTS AND DISCUSSION}

\section{Morphology}

Morphologically all the three plants are distinct in their appearance and can be easily identified. Leaves of all the three species belonging to Asclepiadaceae family, are simple and opposite. Stipules are very small or absent in $L$ reticulata whereas $H$ ada-kodien and $W$ volubilis were ex-stipulated. Comparatively, the petiole is larger in $W$ volubilis and $H$ ada-kodien. The shape of the leaves was ovate to oblong in $L$ reticulata and $H$ ada-kodien whereas $W$ volubilis is having broadly ovate or suborbicular leaves. Leaves of all the three species belonging to Asclepiadaceae family showed reticulate venation with 4-6 pairs of nerves. The texture of leaves was hirtellous in $L$ reticulata whereas in $H$ ada-kodien and $W$ volubilis, leaves were glabrous above and pubescent beneath. The shape of the apex was acuminate in $W$ volubilis, cuspidate in both $L$ reticulata and $H$ adakodien. Leaves of $L$ reticulata were having obtuse or sub cordate base whereas the shape of the base was deeply cordate and rounded in $H$ ada-kodien and $W$ volubilis respectively (table 1 ).

Table 1: Comparative morphology of leaves of three source plants of jivanti

\begin{tabular}{|c|c|c|c|c|}
\hline \multirow{2}{*}{$\begin{array}{l}\text { S. } \\
\text { No. }\end{array}$} & \multirow[t]{2}{*}{ Parameter } & \multicolumn{3}{|l|}{ Results } \\
\hline & & L. reticulata & H. ada-kodien & W. volubilis \\
\hline 1. & Type & Simple & Simple & Simple \\
\hline 2. & Phylotaxy & Opposite & Opposite & Opposite \\
\hline 3. & Stipules & Very small or absent & Exstipulate & Exstipulate \\
\hline 4. & Petiole & $1.1-2.1 \mathrm{~cm}$ & $2.8-4.5 \mathrm{~cm}$ & $3.2-5.8 \mathrm{~cm}$ \\
\hline 5. & $\begin{array}{l}\text { Shape and } \\
\text { size }\end{array}$ & Ovate to oblong, $5-4.7 \mathrm{~cm}$ & $\begin{array}{l}\text { Oblong-ovate, } 8.2-11 \times 3-5.6 \mathrm{~cm} \text {, upper leaves } \\
\text { somewhat triangular }\end{array}$ & $\begin{array}{l}\text { Broadly ovate or suborbicular, } 6.5- \\
14 / 4.5-11 \mathrm{~cm}\end{array}$ \\
\hline 6. & Venation & $\begin{array}{l}6 \text { pairs of nerves with } \\
\text { reticulate venation }\end{array}$ & 4-5pairs of nerves with reticulate venation & Reticulate venation \\
\hline 7. & Texture & $\begin{array}{l}\text { Hirtellous above, } \\
\text { pubescent beneath }\end{array}$ & Glabrous above, thinly pubescent beneath & $\begin{array}{l}\text { Glabrous above, less softly pubescent } \\
\text { beneath }\end{array}$ \\
\hline 8. & Apex & Cuspidate & Cuspidate & Acuminate \\
\hline 9. & Base & Obtuse or subcordate & Deeply cordate, 5-7 glands at the base of midrib & $\begin{array}{l}\text { Rounded, few small glands just } \\
\text { above the petiole. }\end{array}$ \\
\hline
\end{tabular}

Table 2: Comparative microscopical characters of three source plants of jivanti

\begin{tabular}{|c|c|c|c|c|}
\hline \multicolumn{2}{|c|}{ Parameter } & \multicolumn{3}{|l|}{ Results } \\
\hline & & L. reticulata & H. ada-kodien & W. volubilis \\
\hline \multirow{9}{*}{ Petiole } & Shape & Circular & Deeply concave in upper side & Circular \\
\hline & Epidermis & Single layered & Single layered & Single layered \\
\hline & $\begin{array}{l}\text { Epidermal } \\
\text { cells }\end{array}$ & Thin walled and very small & Thin walled and small & Thin walled and small \\
\hline & Cuticle & Thin & Thick & Thin \\
\hline & Trichomes & Multicellular glandular & Multicellular warty & Multicellular, warty \\
\hline & Hypodermis & $\begin{array}{l}\text { 3-4 layers of circular to oval } \\
\text { collenchyma cells with angular } \\
\text { thickenings }\end{array}$ & 2-3 layers of collenchyma cells & 3-4 layers of collenchyma cells. \\
\hline & Cortex & $\begin{array}{l}\text { Thin-walled circular to oval } \\
\text { parenchymatous cells with distinct } \\
\text { intercellular spaces. }\end{array}$ & $\begin{array}{l}5-6 \text { layers of parenchymatous } \\
\text { cells. }\end{array}$ & $\begin{array}{l}\text { Thin-walled circular to oval } \\
\text { parenchymatous cells with large } \\
\text { intercellular spaces. }\end{array}$ \\
\hline & Crystals & Several prismatic crystals are present & $\begin{array}{l}\text { Rosette and prismatic crystals of } \\
\text { calcium oxalate }\end{array}$ & $\begin{array}{l}\text { Several prismatic, rosette crystals are } \\
\text { present }\end{array}$ \\
\hline & $\begin{array}{l}\text { Vascular } \\
\text { bundle }\end{array}$ & $\begin{array}{l}\text { Crescentric bicollateral vascular } \\
\text { bundle, xylem is located in the centre } \\
\text { followed by phloem on both sides. }\end{array}$ & $\begin{array}{l}\text { Arranged in crescenteric shape in } \\
\text { the middle, separated by wide } \\
\text { areas of ground tissue. }\end{array}$ & $\begin{array}{l}\text { Bicollateral vascular bundle, protoxylem } \\
\text { facing towards center and metaxylem } \\
\text { towards the epidermis. }\end{array}$ \\
\hline \multirow{8}{*}{$\begin{array}{l}\text { Mid } \\
\text { rib }\end{array}$} & Shape & Strongly convex & Broadly semi circcular & Strongly convex \\
\hline & $\begin{array}{l}\text { Upper } \\
\text { epidermis }\end{array}$ & Single layer & Single layer & Single layer \\
\hline & Epidermal cell & Barrel-shaped & Oval to rectangular & Barrel-shaped \\
\hline & Trichomes & $\begin{array}{l}\text { Multicellular, glandular warty } \\
\text { trichomes }\end{array}$ & Multicellular warty & Multicellular and glandular trichomes \\
\hline & Cuticle & Thick & Moderate & Thick \\
\hline & Hypodermis & $\begin{array}{l}\text { 1-2 layers of compactly arranged } \\
\text { palisade parenchyma with oil } \\
\text { globules and rich in chloroplast }\end{array}$ & $\begin{array}{l}\text { Single layered, elongated barrel } \\
\text { shaped palisade parenchyma cells } \\
\text { with numerous chloroplasts. }\end{array}$ & $\begin{array}{l}\text { 1-2 layers of palisade parenchyma cells } \\
\text { with chlorophyll pigments and oil } \\
\text { globules }\end{array}$ \\
\hline & Crystals & Rosette crystals of calcium oxalate & Prismatic crystals & Prismatic and rosette crystal \\
\hline & $\begin{array}{l}\text { Vascular } \\
\text { bundle }\end{array}$ & Open and bicollateral vascular bundle & $\begin{array}{l}\text { Open and bicollateral vascular } \\
\text { bundle }\end{array}$ & $\begin{array}{l}\text { Centrally located bicollateral vascular } \\
\text { bundle. }\end{array}$ \\
\hline
\end{tabular}




\section{Microscopy}

Among the three source plants of jivanti, studied for their microscopic characters, the common characters of Asclepiadaceae family and some individual species characters were observed. All these microscopical characters can be used for identification of the species and to differentiate each other. $\mathrm{T} \mathrm{S}$ of $H$ ada-kodien was deeply concave in upper side whereas in $W$ volubilis and $L$ reticulata T S was circular in shape. Epidermis was single layered in all the three species. Cuticle layers are thick in $H$ ada-kodien, $L$ reticulata and $W$ volubilis composed of thin cuticle. Specific characters of Asclepiadaceae family like crescenteric bicollateral vascular bundles, multicellular glandular warty trichomes, prismatic and rosette crystals of calcium oxalate were seen in all the three species.

Transverse section of midrib of $L$ reticulata, $H$ ada-kodien and $W$ volubilis was studied and compared for their identical and differential characters. T $\mathrm{S}$ of mid rib was strongly convex in $L$ reticulata and $W$ volubilis, braodly semicircular in $H$ ada-kodien. Epidermis was single layered and covered with cuticle in all the three species. Epidermal cells were barrel-shaped in $L$ reticulata and $W$ volubilis, oval to rectangular shaped in $\mathrm{H}$ ada-kodien. Multicellular glandular warty trichomes, rosette crystals of calcium oxalate, lactiferous cells were observed in all the three species whereas prismatic crystals were also present in $W$ volubilis. All the three species showed centrally located, open, bicollateral vascular bundle.

\section{Surface study}

Surface study plays an important role in drug identification. The importance of epidermal characters, in general, is widely recognized in taxonomic considerations and in many cases, these are successfully used in the identification of taxa at genus as well as species levels [13]. Similarly, studies in stomata have a great taxonomic as well as pharmacognostic value in the proper identification of medicinal plants [11]. In the present study, stomata were rarely distributed in the upper epidermis in $W$ volubilis whereas stomata were absent in L reticulata and $H$ Ada-kodien. Some of the trichomes and cicatrix were also observed in $W$ volubilis. The lower epidermis composed of paracytic stomata, trichomes and cicatrix in $L$ reticulata and $H$ ada-kodien, paracytic and anisocytic stomata and in $W$ volubilis.

\section{Quantitative microscopy}

All the three source plants composed of a paracytic type of stomata. Size of lactiferous cells, warty trichomes and epidermal cells were larger in $H$ ada-kodien compared to other species. Size of the palisade cells was almost similar in $L$ reticulata and $W$ volubilis whereas it was much smaller in $H$ ada-kodien. Cuticle layer was thicker in $L$ reticulata. Length and the surface measurement of xylem fibres were more in $L$ reticulata. Palisade ratio and stomatal index were higher in $H$ ada-kodien followed by $L$ reticulata (table 3 ).

\section{Powder microscopy}

Characteristic differences in the organoleptic characters like colour, taste, touch were observed in individual powder samples. Different organoleptic characters observed during the study are presented in table 4.

\section{Histochemical study}

Test for lignin, calcium oxalate crystal, starch grain and tannin showed a positive result in all the three samples. (Table 5).

Table 3: Comparative quantitative microscopy of leaves of three source drugs of jivanti

\begin{tabular}{|c|c|c|c|c|}
\hline \multirow[t]{2}{*}{ S. No. } & \multirow[t]{2}{*}{ Parameter } & \multicolumn{3}{|l|}{ Results } \\
\hline & & L reticulata $\mathrm{W}$ and $\mathrm{A}$ & H ada-kodien schult. & W volubilis (Linn. f.) stapf. \\
\hline 1. & Type of stomata & Paracytic & Paracytic & Paracytic \\
\hline 2. & Size of stomata (Length X width) & $0.60 \times 0.30 \mu \mathrm{m}$ & $0.75 \times 0.63 \mu \mathrm{m}$ & $0.8 \times 0.6 \mu \mathrm{m}$ \\
\hline 3. & Lactiferous cavity (surface) & $366.60 \mu \mathrm{m}^{2}$ & $848.68 \mu \mathrm{m}^{2}$ & $498.83 \mu \mathrm{m}^{2}$ \\
\hline 4. & Xylem measurement from proto to metaxylem & $119.08 \mu \mathrm{m}$ & $102.95 \mu \mathrm{m}$ & $106.11 \mu \mathrm{m}$ \\
\hline 5. & Xylem surface measurement & $861.25 \mu \mathrm{m}^{2}$ & $770.42 \mu \mathrm{m}^{2}$ & $391.71 \mu \mathrm{m}^{2}$ \\
\hline 6. & Rosette crystals & $329.31 \mu \mathrm{m}^{2}$ & $436.78 \mu \mathrm{m}^{2}$ & $568.12 \mu \mathrm{m}^{2}$ \\
\hline 7. & Warty trichome & $3735.54 \mu \mathrm{m}^{2}$ & $7320.29 \mu \mathrm{m}^{2}$ & $3845.65 \mu \mathrm{m}^{2}$ \\
\hline 8. & Palisade cell measurement & $1040.41 \mu \mathrm{m}$ & $406.65 \mu \mathrm{m}$ & $1080.48 \mu \mathrm{m}^{2}$ \\
\hline 9. & Epidermal cell measurement & $217.11 \mu \mathrm{m}^{2}$ & $419.99 \mu \mathrm{m}^{2}$ & $212.64 \mu \mathrm{m}^{2}$ \\
\hline 10. & Cuticle layer measures & $32.42 \mu \mathrm{m}$ & $25.13 \mu \mathrm{m}$ & $18.55 \mu \mathrm{m}$ \\
\hline 11. & Stomatal index & 25 & 27 & 3 \\
\hline 12. & Palisade ratio & 3 & 4 & 2.5 \\
\hline
\end{tabular}

Table 4: Organoleptic characters of the three source drug of jivanti

\begin{tabular}{llll}
\hline Organoleptic characters & Leptadenia reticulata W and A & Holostemma ada-kodien schult & Wattakaka volubilis L. f \\
\hline Colour & Light green & Dark green & Light green \\
Taste & Slightly bitter & Sweet and bitter & Slightly sweet and bitter \\
Touch & Smooth & Smooth & Smooth \\
Odour & Characteristic & Characteristic & Characteristic \\
\hline
\end{tabular}

Diagnostic character like paracytic stomata, rosette crystals of calcium oxalate, and lacticiferous cells were observed in all the three species. $L$ reticulata and $H$ ada-kodien showed multicellular warty trichomes whereas multicellular and glandular trichomes were observed in Wattakaka volubilis.

Table 5: Histochemical study of three botanical source drug of jivanti

\begin{tabular}{|c|c|c|c|c|c|}
\hline Reagents & Test for & Observation & L. reticulata & H. ada-kodien & W. volubilis \\
\hline Phloroglucinol+Conc HCL & Lignin & Red colouration & ++ & ++ & ++ \\
\hline Phloroglucinol+Conc HCL & Calcium oxalate crystal & Dissolved & ++ & ++ & ++ \\
\hline Iodine & Starch & Blue & ++ & ++ & ++ \\
\hline Ferric chloride solution & Tannin & Blue-black colouration & ++ & ++ & ++ \\
\hline
\end{tabular}

\footnotetext{
‘++' Present
} 


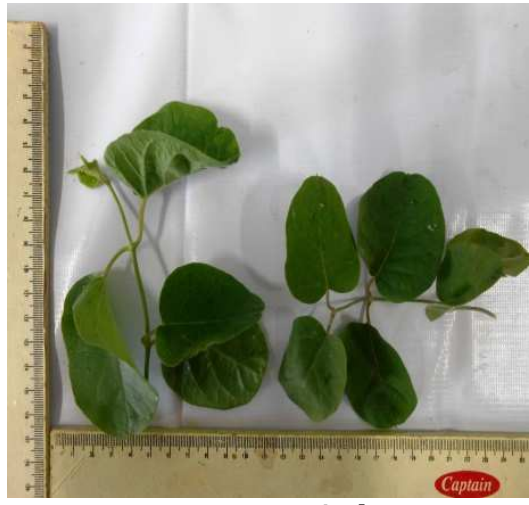

A.

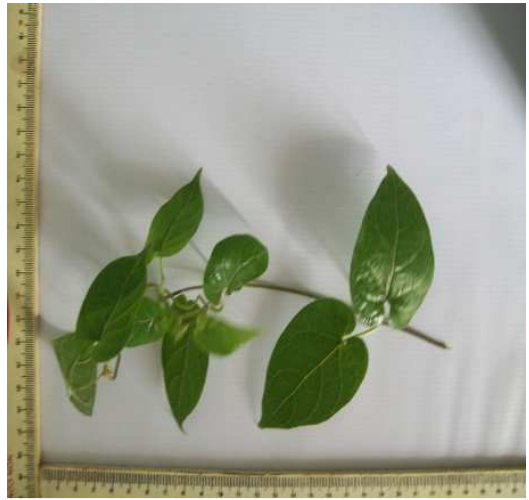

B. H. ada-kodein

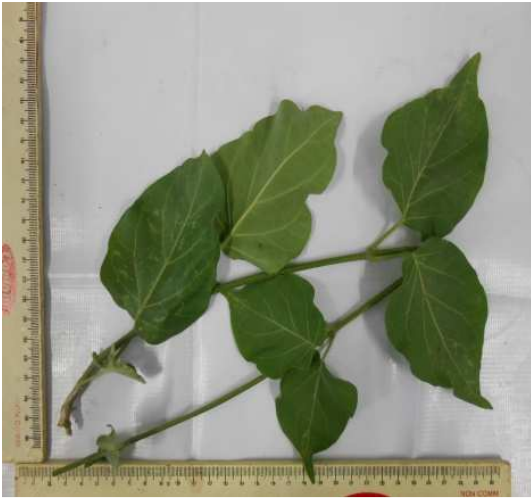

C. W. volubilis

Fig. 1: Morphological characters of three source plants of jivanti

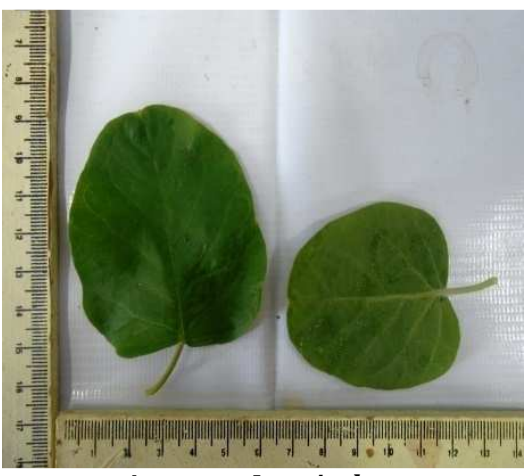

A.

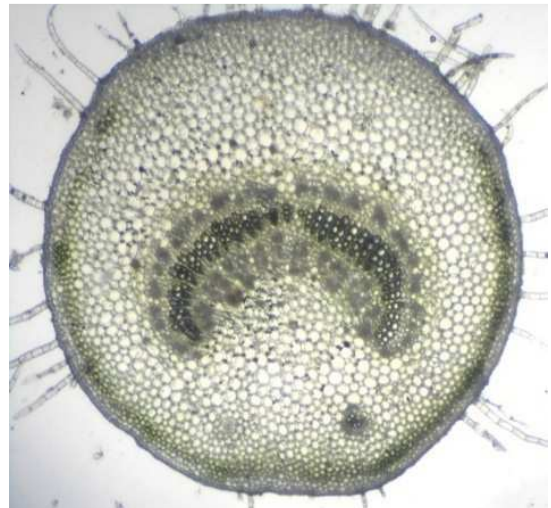

A.

L. reticulata

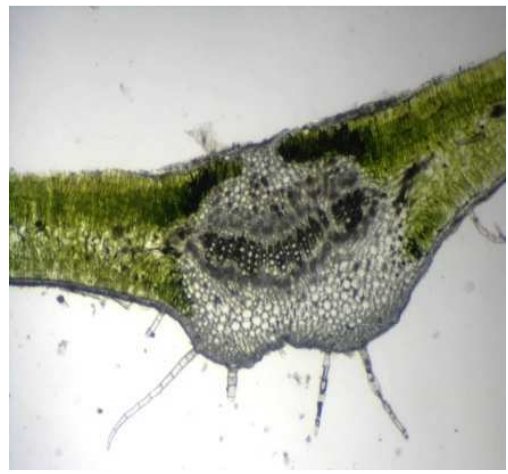

A. L. reticulata

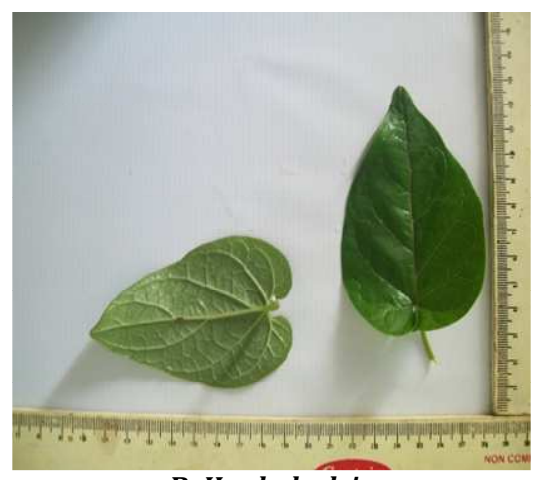

B. H. ada-kodein

Fig. 2: Measurement of leaves

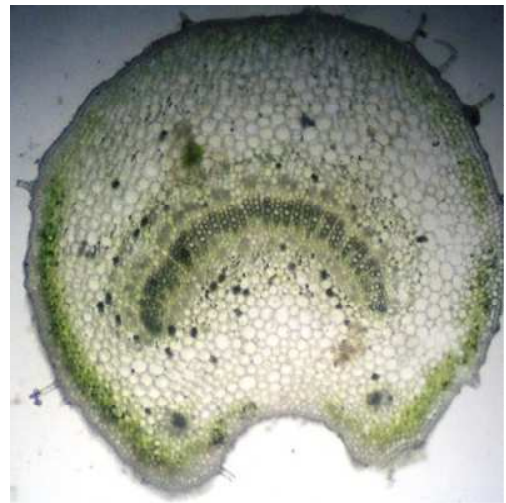

B. H. ada-kodein

Fig. 3: T S of petiole

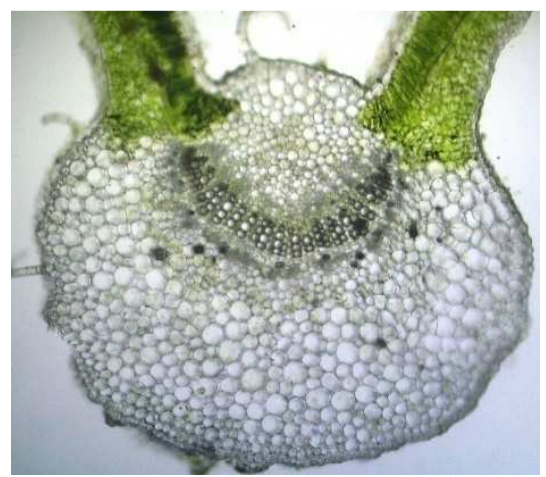

B. H. ada-kodein

Fig. 4: T S of mid rib

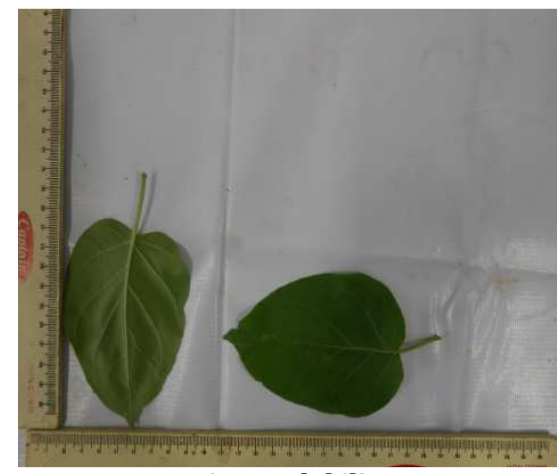

C. W. volubilis

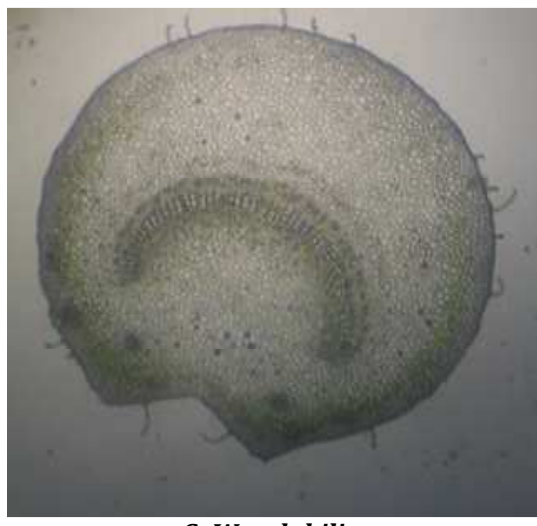

C. W. volubilis

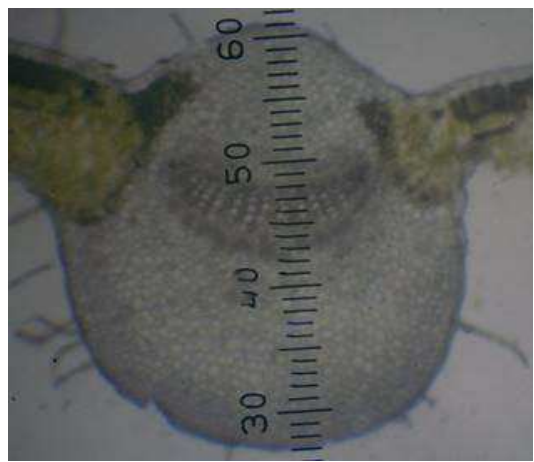

C. W. volubilis 


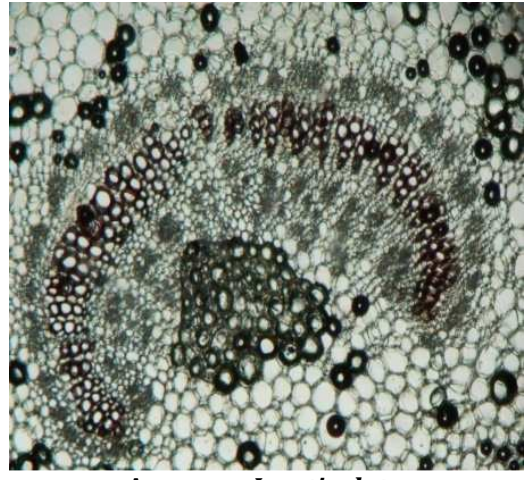

A.

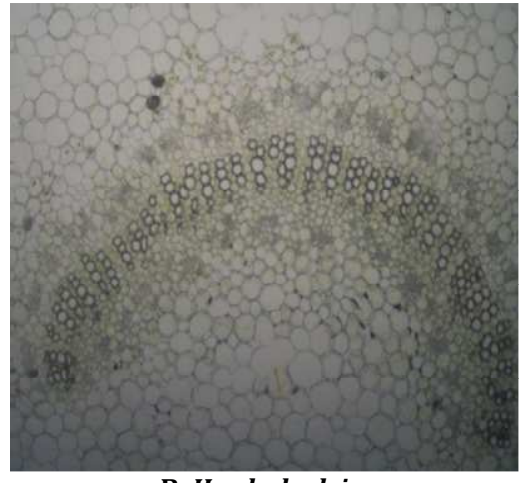

B. H. ada-kodein

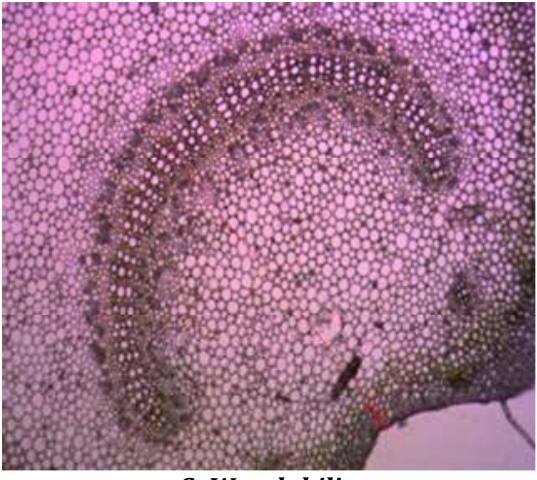

C. W. volubilis

Fig. 5: T S of petiole showing vascular bundle

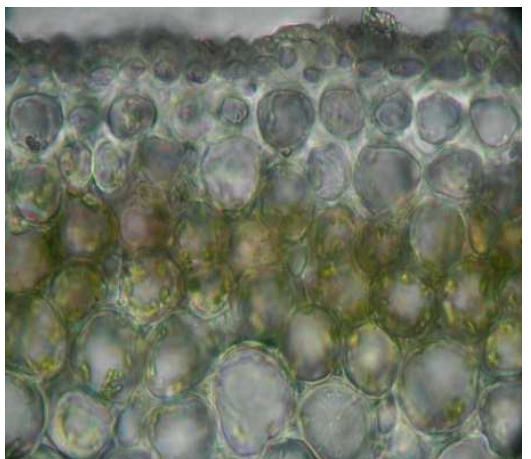

A.

L. reticulata

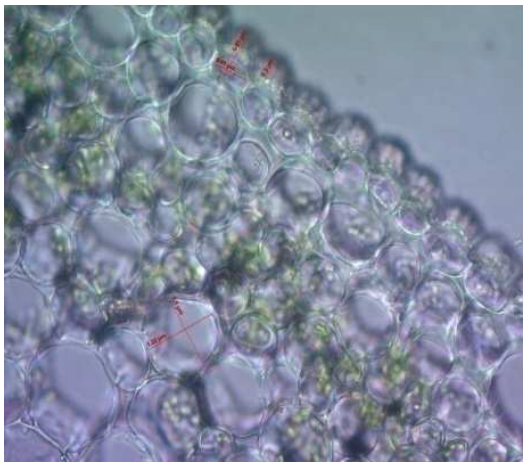

B. H. ada-kodein

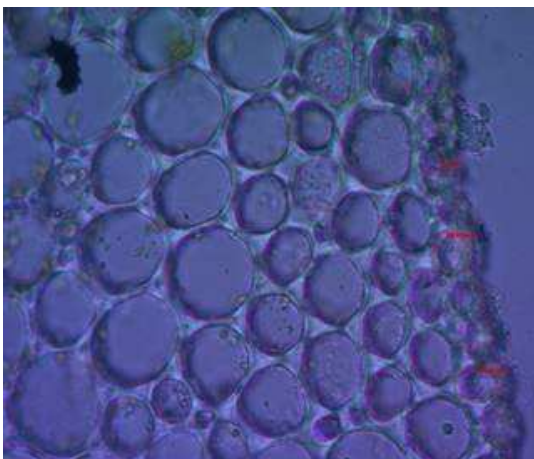

C. W. volubilis

Fig. 6: T S of petiole showing epidermis and hypodermis

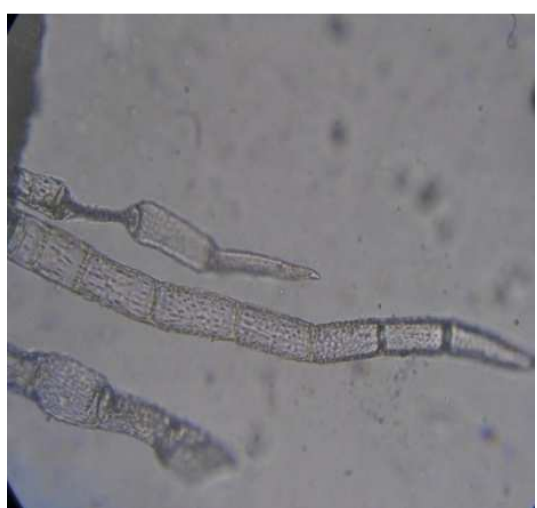

A.

L. reticulata

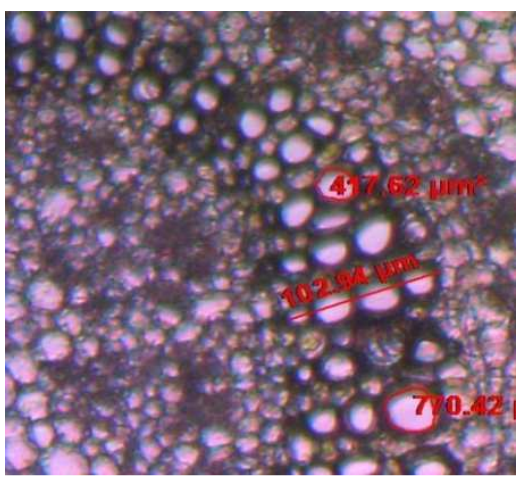

A.

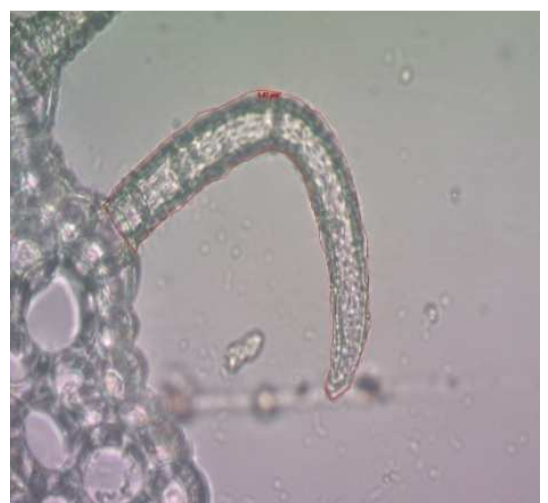

B. H. ada-kodein

Fig. 7: T S of petiole showing trichomes

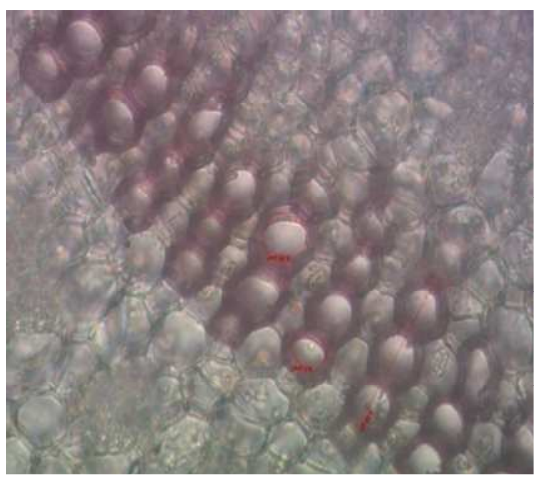

B. H. ada-kodein

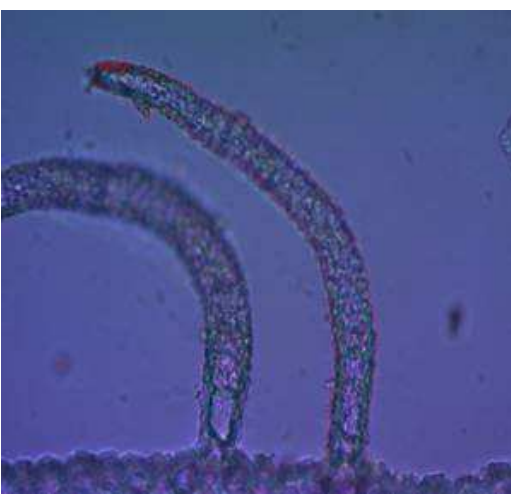

C. W. volubilis

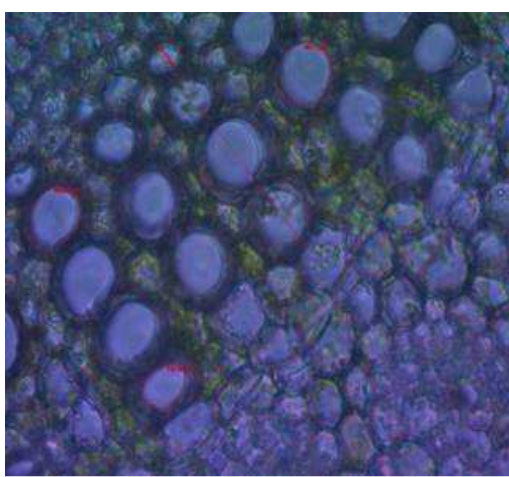

C. W. volubilis

Fig. 8: T S of petiole showing xylem fibres 


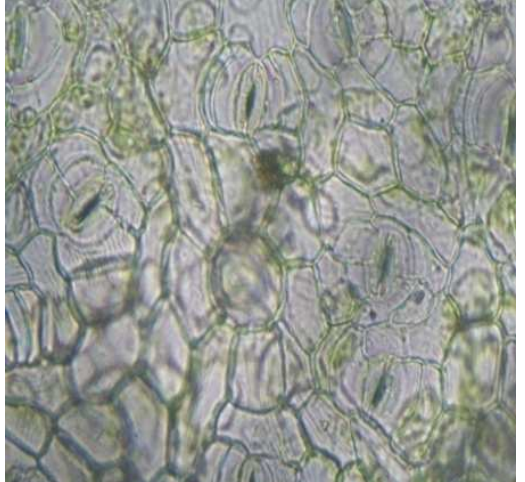

A.

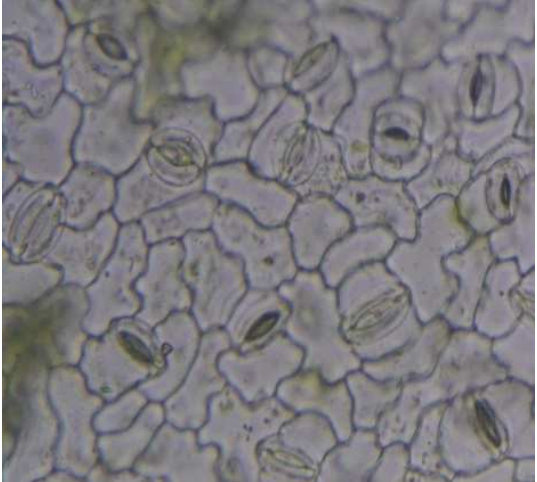

B. H. ada-kodein

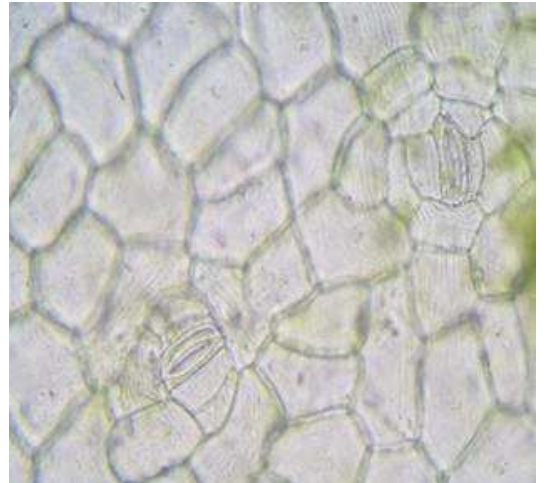

C. W. volubilis

Fig. 9: Surface study

\section{CONCLUSION}

The observed macroscopical and microscopical characters are useful for the identification and differentiation of closely related species used in the name of jivanti. The results of comparative quantitative microscopy are reported for the first time. These observations are specific to the species and can be considered as the diagnostic characters of the individual sample.

\section{AUTHORS CONTRIBUTIONS}

Dr Raghavendra Naik conceptualized, designed, carried out the work and drafted the article. Dr Rabinarayan Acharya, conceptualized, designed, monitored the work and edited the article. Dr Harisha C R supervised the experimental study and edited the manuscript.

\section{CONFLICT OF INTERESTS}

The authors do not have any conflict of interest to declare.

\section{REFERENCES}

1. Bhavamishra: Chunekar KC, Pandey GS. Bhavaprakasha Nighantu, Guduchyadi Varga. $1^{\text {st }}$ ed. Varanasi: Chaukhambha Bharati Academy; 2004.

2. Sharma PC, Yelne MB, Dennis TJ. Database on medicinal plants used in ayurveda. $1^{\text {st }}$ ed. New Delhi: Department of ISM and $\mathrm{H}$, the ministry of health and family welfare, Government of India; 2001.
3. Kumar RK. Comparative phytochemical analysis of Leptadenia reticulata W. and A. and Dregia volubilis Linn. (Source of jivanti). Jamnagar: M. Sc. Med. Plants, Institute for Ayurvedic Medicinal Plant Science, Gujarat Ayurved University; 2006.

4. Kumar S, Kumar V, Prakash O. Microscopic evaluation and physiochemical analysis of Dillenia indica leaf. Asian Pac J Trop Biomed 2011;1:337-40.

5. Nasreen S, Radha R. Assessment of quality of withania somnifera dunal (Solanaceae)-pharmacognostical and physicochemical profile. Int J Pharm Pharm Sci 2011;3:152-5.

6. Saxena H. 0: The Flora of Orissa. $1^{\text {st }}$ ed. Bhubaneshwar: Regional Research Laboratory; 1995.

7. Gopalakrishna BK. Flora of Udupi. $1^{\text {st }}$ ed. Manipal: Manipal Press Limited; 2003.

8. Khandelwal KR. Practical pharmacognosy-techniques and experiments. $19^{\text {th }}$ ed. Pune: Nirali Prakashan; 2008.

9. Anonymous. The Ayurvedic Pharmacopoeia of India. $1^{\text {st }}$ ed. New Delhi: Ministry of Health and Family welfare, Department of I. S. M. and H, Govt. of India; 1999.

10. Wallis TE. Textbook of pharmacognosy. $5^{\text {th }}$ ed. London: Churchill Publication; 1985.

11. Trease GE, Evans WC. Trease and evans pharmacognosy. California: Harcourt brace and Co; 2002.

12. Krishnamurty KV. Methods in the plant histochemistry. Madras: Vishwanadhan Pvt Limited; 1988.

13. Rao RS, Ramayya N. Trichome types and their taxonomic importance in the tiliaceae. Indian J Bot 1987;10:65-73. 